\title{
The evaluation of DiGeorge syndrome gene deletion using molecular cytogenetic techniques
}

\author{
Abeer A. Bahamat ${ }^{1 *}$, Sahira A. Lary ${ }^{2}$, Abdul Ali Peer Zada ${ }^{3}$, Mohammed H. AL-Qahtani ${ }^{4}$ \\ From 2nd International Genomic Medical Conference (IGMC 2013) \\ Jeddah, Kingdom of Saudi Arabia. 24-27 November 2013
}

\section{Background}

Di-George Syndrome (DGS) is known as 22q11.2 deletion syndrome. It is a genetic disorder that is being recognized with increasing frequency with a documented incidence of approximately 1 in 4000 and is the most common human deletion syndrome, typically present early in life and is rarely appearing in adult patients (1). Micro-deletion of chromosome 22q11.2 is one of the most clinically variable syndromes, with more than 180 features associated with the deletion. The syndrome is caused by genetic deletions (loss of a small part of the genetic material) found on one of the two 22nd chromosomes (2). Very rarely, patients with similar clinical features may have deletions on the chromosome 10. An accurate diagnosis is needed for the proper management of affected cases. Diagnosis relies on conventional cytogenetic and Fluorescent In Situ Hybridization (FISH) techniques. The newly developed technique, array Comparative Genomic Hybridization (aCGH), allows

Table 1 Summary of the results of GTG-banding, FISH technique and aCGH technique in patients with DiGeorge syndrome

\begin{tabular}{|c|c|c|c|}
\hline ID & Cytogenetic Results & Fish Results & Array-CGH Results \\
\hline 1 & $46, X X$ & 46,XX.ish del(22)(q11.2q11.2) & $\operatorname{del}(22)(q 11.21 q 11.23)$ \\
\hline 2 & $46, X Y$ & no deletion & no deletion \\
\hline 3 & $46, X X$ & no deletion & no deletion \\
\hline 4 & $46, X Y$ & no deletion & no deletion \\
\hline 5 & $46, X X$ & no deletion & $\operatorname{del}(22)(q 11.21)$ \\
\hline 6 & $46, X X$ & no deletion & no deletion \\
\hline 7 & $46, X X$ & no deletion & $\operatorname{del}(22)(q 11.23)$ \\
\hline 8 & $46, X Y$ & no deletion & $\operatorname{del}(22)(q 11.23)$ \\
\hline 9 & $46, X Y$ & no deletion & no deletion \\
\hline 10 & $46, X X$ & no deletion & no deletion \\
\hline 11 & $46, X Y$ & no deletion & no deletion \\
\hline 12 & $46, X X, \operatorname{del}(22)(q 11.2)$ & $46, X X$,del(22)(q11.2).ish del22(q11.2q11.2) & $\operatorname{del}(22)(q 11.21 q 11.23)$ \\
\hline 13 & $46, X X$ & no deletion & no deletion \\
\hline 14 & $46, X X$ & no deletion & no deletion \\
\hline 15 & $46, X X$ & no deletion & no deletion \\
\hline 16 & $46, X Y$ & no deletion & $\operatorname{del}(22)(q 11.23)$ \\
\hline
\end{tabular}

\footnotetext{
* Correspondence: aaab79ab@hotmail.com

'Diagnostic Genomic Medicine Unit (DGMU), King Abdulaziz University,

Jeddah, KSA

Full list of author information is available at the end of the article
}

C Biomed Central

() 2014 Bahamat et al; licensee BioMed Central Ltd. This is an Open Access article distributed under the terms of the Creative Commons Attribution License (http://creativecommons.org/licenses/by/2.0), which permits unrestricted use, distribution, and reproduction in any medium, provided the original work is properly cited. 
Table 1 Summary of the results of GTG-banding, FISH technique and aCGH technique in patients with DiGeorge syndrome (Continued)

\begin{tabular}{|c|c|c|c|}
\hline 17 & $48, X X X X$ & no deletion & no deletion \\
\hline 18 & $46, X X$ & no deletion & no deletion \\
\hline 20 & $46, X X$ & no deletion & no deletion \\
\hline 21 & $46, X Y$ & no deletion & no deletion \\
\hline 22 & 46,XX,del(18)(p11.2) & no deletion & $\operatorname{del}(22)(q 11.23)$ \\
\hline 24 & $46, X Y$ & no deletion & no deletion \\
\hline 25 & $46, X Y$ & no deletion & no deletion \\
\hline 26 & $46, X X$ & no deletion & no deletion \\
\hline 27 & $46, X Y$ & no deletion & $\operatorname{del}(22)(q 11.23)$ \\
\hline 28 & $47, X X,+18$ & no deletion & no deletion \\
\hline 29 & $46, X X$ & no deletion & no deletion \\
\hline 30 & $46, X X$ & no deletion & no deletion \\
\hline Total & 1 & 2 & 8 \\
\hline$\%$ & $3.6 \%$ & $7.1 \%$ & $28.6 \%$ \\
\hline
\end{tabular}

for detection of minor deletions or duplications in the whole genome (3). The purpose of this study is to compare the effectiveness of using these techniques in detecting the deletion of chromosome 22q11.2.

\section{Materials and methods}

The study included 30 suspected DGS patients depending on their symptoms, referred to the DGMU for genetic diagnosis. We used GTG-banding technique,

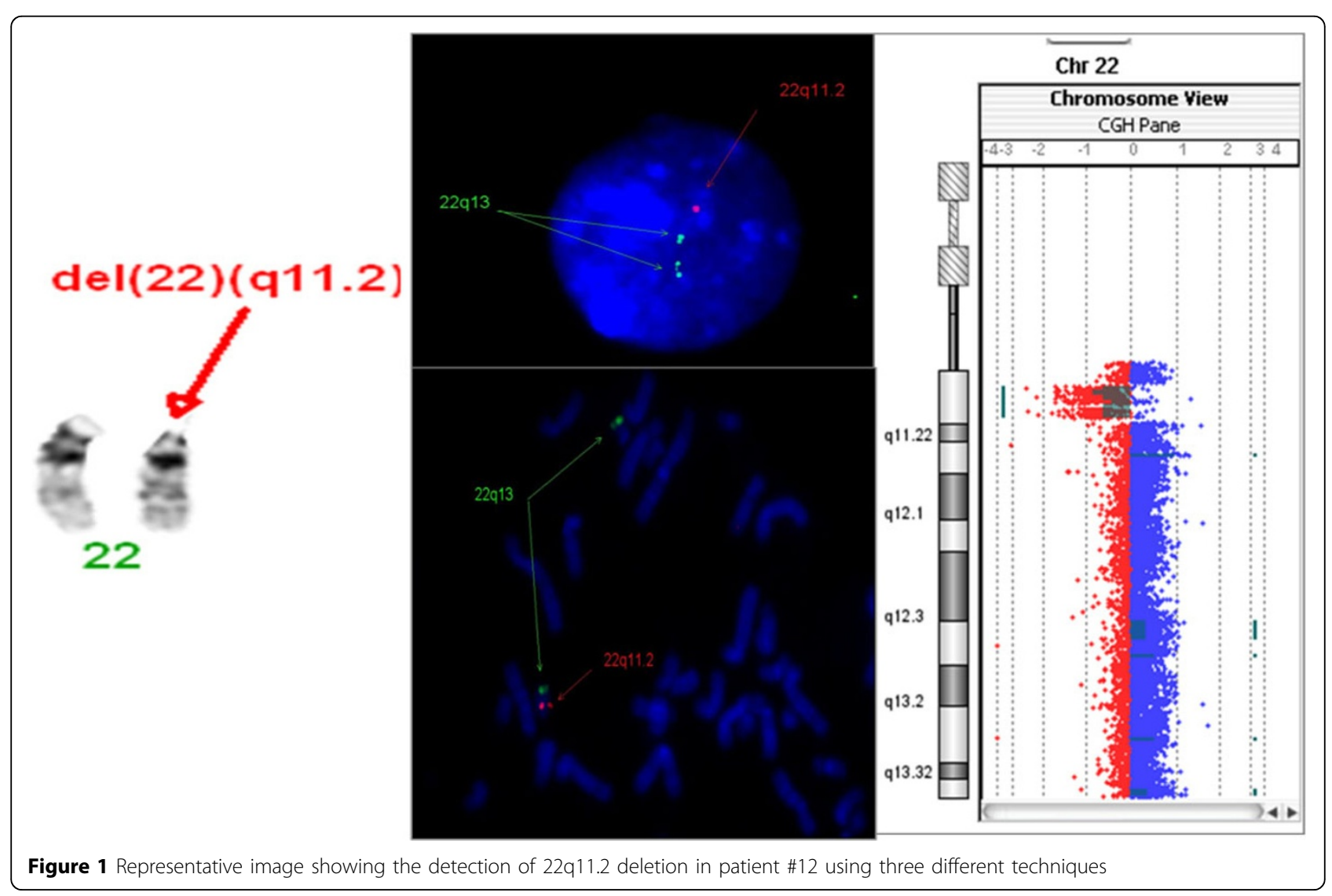


FISH (Fluorescence in situ Hybridization) and ArrayCGH (Comparative Genomic Hybridization) techniques for the detection of deletion in chromosome 22 for all patients.

\section{Results}

Cytogenetic technique could detect the 22q11.2 deletion in $1 / 30$ patients, however, other chromosomal aberrations were detected in three patients $(48, \mathrm{XXXX} / 46, \mathrm{XX}$,del(18) (p11.2)/ 47,XX,+18). Results of FISH technique had shown the $2 \mathrm{q} 11.2$ deletion in $2 / 30$ patients. The application of aCGH technique has shown deletions in different loci on chromosome 22 in $8 / 30$ patients as shown in Table (1) and Figure (1).

\section{Conclusions}

Array-CGH technique could detect a larger number of genome deletions or duplications in affected patients compared to FISH and cytogenetic analysis. Array-CGH is a highly sensitive technique because it depends on the scanning of the whole genome in each patient; therefore any other cryptic chromosomal aberration either a gain or loss can be accurately detected. Cytogenetic G-banding and High - resolution banding techniques could detect other chromosome aberrations such as translocation or deletion in other chromosomes. In FISH, the probe used will enable detection of a specific region only and may not cover the entire DGS region. The limitation can be overcome to some extent by use of different probes to screen the entire gene. We, therefore conclude that array-CGH is a highly sensitive technique compared to cytogenetic and FISH in the diagnosis of DGS.

\footnotetext{
Authors' details

${ }^{1}$ Diagnostic Genomic Medicine Unit (DGMU), King Abdulaziz University, Jeddah, KSA. ${ }^{2}$ Biochemistry Department, Collage of Science, King Abdulaziz University, Jeddah, KSA. ${ }^{3}$ Pathology and Clinical Laboratory Medicine, King Fahad Medical City, Riyad, KSA. ${ }^{4}$ Centre of Excellence in Genomic Medicine Research, King Abdulaziz University, Jeddah, KSA.
}

Published: 2 April 2014

\section{References}

1. Shaffer LG, Ledbetter DH, Lupski JR: Molecular Cytogenetics of Contiguous Gene Syndromes. Mechanisms and Consequences of Gene Dosage Imbalance, Metabolic and Molecular Basis of Inherited Disease 2001, 1291.

2. Halder A, Jain M, Chaudhary I, Kabra M: Prevalence of 22q11. 2 Microdeletion in 146 Patients with Cardiac Malformation in a Referral Hospital of North India. BMC medical genetics 2010, 1:101.

3. Theisen A: Microarray-Based Comparative Genomic Hybridization (Acgh). Nature Education 2008, 1.

doi:10.1186/1471-2164-15-S2-P30

Cite this article as: Bahamat et al:: The evaluation of DiGeorge syndrome gene deletion using molecular cytogenetic techniques. $B M C$ Genomics 2014 15(Suppl 2):P30.

\section{Submit your next manuscript to BioMed Central} and take full advantage of:

- Convenient online submission

- Thorough peer review

- No space constraints or color figure charges

- Immediate publication on acceptance

- Inclusion in PubMed, CAS, Scopus and Google Scholar

- Research which is freely available for redistribution

Submit your manuscript at www.biomedcentral.com/submit 